\title{
二,三日常食品のビタミン E活性 \\ The Vitamin E Activity of Some of Our Foods
}

（昭 和 41 年 11 月 10 日 受 理)

小柳達男和田世つ* 古川令子

(Tatsuo Koyanagi) (Setsu Wada) (Ryoko Furukawa).

\begin{abstract}
Commonly used foods in Japan have been biologically analyzed for their vitamin E content. One of the two kinds of frying oil examined by us, one mayonnaise and cabbage showed almost no activity. Some activity was present in the other frying oil, alcohol extract of soybean, and that of unpolished rice. The presence of vitamin $\mathrm{E}$ activity in unpolished rice was confirmed by chemical method. And the very great loss of vitamin $\mathrm{E}$ due to the processing of rice is illustrated by chemical analysis.
\end{abstract}

ビタミンE (V.E) には $\alpha, \beta, \gamma, \delta, \varepsilon, \zeta$ おび $\eta$ のよ 5に多くの同族体があるが生理的活性は $\alpha$ だけが強く， 他のものは著しく劣っている。しかるに植物の種類によ って同族体の種類および量が異なっていて, ダイズのよ ラに $\alpha$ が少なくてrたけとくに多いるのあある。

そこでわれわれは二, 三日常食品中のV.Eを, ネズミ の䋈殖を順調に進行させる作用をめやすにして判定して みた。ここにその結果の大要を報告する。

\section{方法}

V.Eの検定法はKing ${ }^{1)}$ 方法を多少改变して行なった 飼育 ドンリュー系雌ネズミ（体重40～60 g）のbのを デンプン 66 , 豚脂 (局方) 5 , カゼイン 18 , ビール酵母 5 , 塩類混合（田辺了ミノ酸研究基金, 大阪市） 4 , 肝 油（局方） $2 （ \%)$ よりなるV. E欠乏飼料で約 2 力月飼 育し，体内のV.Eの貯蔵をなくすようにした。対照区に はV.E給源として，ユペラ末（エーザイ株式会社, 東京 都）により上記飼料のほかに毎日 $3 \mathrm{mg}$ のV.Eを添加し

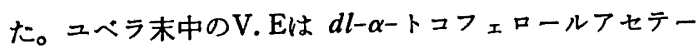
トである。

対照区の飼料を与えてあらかじめ飼有していた成就雄 ネズミと 2 週間同居させ,スメア法により交尾を認めた あのは直ちに 1 匹飼とし, V. E欠乏飼料ととすに 3 日間 可検試料を与えた。

試料 試験に供したものはダイズのエーテルあるいはフ ルコール抽出油, 玄米のアルコール抽出油, マヨネーズ から分離した油, 市販てんぷら油, サラダ油, キャペッ などである。がイズ抽出油は粉硉したがイズをェーテル
抽出して, 抽出液からエーテルを蒸発したのち, 窒菜ガ スを30分間吹き込んで少量ずつアンプールに声めておい た。アルコール抽出のばあいは精製した無水アルコール で加熱抽出し，㴓液を減圧演維したものを用いた。玄米 からあ同様な方法でフルコール抽出油を作った。マヨネ 一ズは同量の熱水を加えて数分間加熱し，遠心分離して 上層の油を集めた。

投与法 抽出油あるいは食用油類は試験するときV.E欠 そ飼料のラードとおきかえ，1 日 1 匹当たり $1 \mathrm{~g}$ の割合 で 3 日間，1日分飼料投与に先たって，少量の飼料にま ぜて与えた。キャベッだけは冬季 2 月のもので外部の緑 葉だけをとり，総量 210 gを 3〜5 日にわたり数回にわ けて新鮮なるのを給与した。

妊娠経過19日目にェーテル麻酔下に開腹し子宮, 卵巣 をとり出し, 排畉数(黄体数), 着床数, 生胎児数拈よび 各種缄器重量などを测定し，V.Eを与えない群および

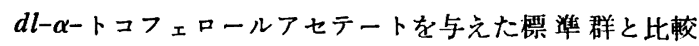
した。

V.Eの化学的定量 アセトン抽出して Edwin ${ }^{2)} の$ 万 法によって定量した。

$$
\text { 結果 }
$$

前後 2 回行なった試驗成績は第 1 表扣よび第 2 表に示 した。交配するまでの成声はV.Eを与えぬほうは 1 日平

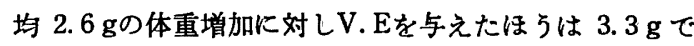
あって，V.E を与えたほうが発育がすぐれていた。妊 娠率は第 1 回, 第 2 回の試験とも95\%でこの5ち偽妊娠 が 10\% ほどありこれは試験から除外した。正常群，試 


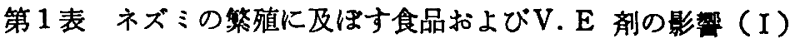

\begin{tabular}{|c|c|c|c|c|c|}
\hline & 無 添 加 & $\begin{array}{l}\text { ダイズエーテル } \\
\text { 抽～出 }\end{array}$ & $\begin{array}{l}\text { 市肘(A) } \\
\text { ChS゚ら油 }\end{array}$ & $\begin{array}{l}\text { 霜肘飼 } \\
\text { 料 } \\
\text { 郕 }\end{array}$ & V.E 剤 \\
\hline 動＼cjkstart物 & 11 & 8 & 9 & 8 & 5 \\
\hline 平均母体重 (g) & 220 & 235 & 250 & 269 & 310 \\
\hline 平均屠体重 & 134 & 142 & 145 & 154 & 156 \\
\hline 排 卵 数 平 均 & 10.7 & 11.5 & 11.7 & 11.5 & 12.0 \\
\hline 着 床 数 平 均 & 9.5 & 10.4 & 10.5 & 11.0 & 11.2 \\
\hline 生 胎 児 数 平 均 & 0 & 0.25 & 0 & 5.0 & 9.8 \\
\hline 生胎児総重量平均（ $\mathrm{g} /$ 腹） & 0 & 0.47 & 0 & 11.80 & 23.47 \\
\hline 生胎児平均重量 $(\mathrm{g} /$ / & 0 & 1.88 & 0 & 2.36 & 2.39 \\
\hline 着床前死亡 /排卵数 （\%) & 11.0 & 9.8 & 9.5 & 4.3 & 8.3 \\
\hline 着床後死亡/排卵数 & 89.0 & 88.0 & 90.5 & 52.2 & 10.0 \\
\hline
\end{tabular}

第2表 ネズミの繁殖に及ばす食品およびV.E 剤の影響（II）

\begin{tabular}{|c|c|c|c|c|c|c|c|c|c|c|}
\hline & 正 常 & 無添加 & $\mid \begin{array}{l}\mid \text { ダイスフ } \\
\text { ルコール } \\
\text { 抽出油 }\end{array}$ & $\begin{array}{l}\text { 玄米アル } \\
\text { בール抽 } \\
\text { 出油 }\end{array}$ & $\begin{array}{l}\text { マショ } \\
\text { ズの油 }\end{array}$ & $\left|\begin{array}{|l}\exists \\
\text { サラダ油 }\end{array}\right|$ & $\begin{array}{l}\text { 貶(A) } \\
\text { ん.55 }\end{array}$ & $\begin{array}{l}\text { 萳販(B) } \\
\text { 油 } \\
\text { 油 }\end{array}$ & キャベッ & V. E 骩 \\
\hline 物 & 4 & 3 & 6 & 7 & 6 & 6 & 6 & 6 & 6 & 4 \\
\hline 平均 母体 重 $(\mathrm{g})$ & 309 & 282 & 282 & 270 & 278 & 289 & 289 & 248 & 262 & 314 \\
\hline 平均屠 体 重 $(\mathrm{g})$ & 161 & 1 & 154 & 161 & 163 & 168 & 160 & 146 & 155 & 155 \\
\hline 排 卵 数 平 均 & 12.0 & 1.0 & 12.7 & 11.9 & 12.5 & 10.8 & 11.5 & 12.1 & 11.0 & 11.5 \\
\hline 着 床 数 平 均 & 11.2 & 8.7 & 12.1 & 9.9 & 12.5 & 10.0 & 11.0 & 11.7 & 9.5 & 11.3 \\
\hline 生 胎 児 数 平 均 & 10.8 & 0 & 2.0 & 0.9 & 0 & 1.5 & 2.3 & 0 & 0 & 10.8 \\
\hline 生胎児総重量平均( $\mathrm{g} /$ /腹) & 22.68 & 0 & 4.11 & 1.57 & 0 & 4.81 & 5.27 & 0 & 0 & 26.84 \\
\hline 生胎児平均重量 $(\mathrm{g} /$ /匹) & 2.11 & 0 & 2.05 & 1.83 & 0 & 3.32 & 2.25 & 0 & 0 & 2.51 \\
\hline 着床前死亡/排卵数 (\%) & 6. & 1.2 & 3.9 & 16.9 & 0 & 7.7 & 4.3 & 4.1 & 13.6 & 2.2 \\
\hline 着床後死亡 /排卵数 (\%) & 4.2 & 78.8 & 80.3 & 75.9 & 100.0 & 78.4 & 75.3 & 95.9 & 86.4 & 4.3 \\
\hline
\end{tabular}

験群いずれも同樣に妊娠したが，妊娠後もV.E久乏飼料 のみを与えたるのは例外なく11〜12日目より流産しはじ め, 生胎児はまったく存在しなかった。またフライ油, マヨネーズの油扰よびキャベッの群も同様にことごとく 流産した。

これら流産したものは排卵数に関しては他の正常な妊 娠をしたものと比較すると大差はなかった。しかし生胎 児数は投与試料によって異なり，一腹の平均生胎児数は 標準児が 9.8〜10.8頭に対し他は著しく少なく，ダイズ および玄米のアルコール抽出物は平均 $0.25 \sim 2.0$ 頭, 市 眅油類ではフライ油で効果のあったものでも 2,3 頭に すぎなかった。着床数は試験群間でばらつきが生胎児数 ほど大きな差はなかった。

生胎児の平均重量は一般火生胎児数の多いほど胎児は 小さい傾向があるものであるが，本試験では反対に生胎 児数の少ないものが小さいことが認められた。

な扰玄米扰よびダイズのフルコール抽出物量を 2 倍に して各 1 頭のネズミに与えたところ生胎児数が正常にな ることを認めた。
表に示した着床後死亡総数/排卵総数の百分率は各試 料のV.E効果を示するのであるが, 各試料間に大きな差 があることが明らかである。なお母ネズミはV.E欠乏の 有無に上る肝, 腎, 脾, 心臓, 副腎, 脳下垂体の重量に は変化がなかった。

$$
\text { 考察 }
$$

Harris $^{3)}$ や Green ら ${ }^{4}$ の報告した食品中V.Eの化学的 定量成績を第 3 表に示した。この成績でみると植物油で はサフラワー油扣よび棉実油に $\alpha$ 型V.Eがあるががイズ 油, コーン油には $\alpha$ 型は少ない。市販の植物油中には混 合されたものもあるので同じてんぷら油でもわずかに生 理効果を示するのと, 全く効果を示さないるのとがあっ た。われわれは日常使用する植物油にV.E效果がすっと あるであろらと期待したが意外に少なかった。棉実油に は $\alpha$ 型があるのでこれを原料とするマヨネーズに生理効 果があろらかと思ったがこれるまったく無効で期待はず れであった。

ダイズ油を主体とするてんぷら油はV.Eの効果がほと 
第 3 表 食品中 V.E の化学的定量成䋶

(Harris 1950, Green 1955)

\begin{tabular}{|c|c|c|c|c|}
\hline 食 & 品 & $\begin{array}{l}1 \mathrm{Emg} / \\
100 \mathrm{~g} \text { 食品 }\end{array}$ & 棇 $\begin{array}{r}\mathrm{Em} / \\
\mathrm{g} \text { 油 }\end{array}$ & $\alpha-\mathrm{E} \mathrm{mg} / \mathrm{g}$ 油 \\
\hline ダ & 油 & & 1.4 & 0.1 \\
\hline$z-y$ & 油 & & 0.9 & 0.1 \\
\hline サフラワー & -油 & & 0.5 & 0.5 \\
\hline 棉＼cjkstart実 & 油 & & 0.9 & 0.6 \\
\hline$\therefore \quad タ$ & & & 0.02 & \\
\hline マーガリ & & & 0.5 & 0.3 \\
\hline 牛 肝 & 臓 & 1.4 & 0.3 & 0.3 \\
\hline \$ & ラ & 0.4 & 0.7 & 0.6 \\
\hline 鷄 & 卵 & 2.0 & 0.2 & 0.1 \\
\hline 玄 & 米 & 2.4 & 1.1 & 0.6 \\
\hline 白 & 米 & 0.6 & 1.2 & 0.7 \\
\hline 小＼cjkstart麦 & 粉 & 1.2 & 0.9 & 0.9 \\
\hline パ & ン & 0.2 & 0.2 & 0.2 \\
\hline
\end{tabular}

んどなかったが，大豆のアルュール抽出物はわずかであ るが効果を示した。ネズミの数が少ないので，この表に は示さなかったが抽出物の量を 2 倍に增すと標準区と同 等の效果を示した。玄米のアルコール抽出物のばあいも V.E効果がわずかにあり,これも抽出物の量を 2 倍にし てネズミ1頭に与えてみた結果正常な繁殖をすることを 認めた。それゆえ米は大豆とともにわれわれにとって重 要なV.E資源であると考えることができる。

野菜はV.E資源としては価値が低いといわれていたが われわれのキャベッの実験ですそれが示された。第 3 表 ではタラの脂肪の中にV.Eがあるようになっているが， 魚油の上うな高度不飽和脂肪酸を含んだすのを食べると V.Eの要求が高まるので，V.Eを含んでいててV.Eの効 果を打消してしまうから V.E 資源としては期待できな い。

米国では日常食のV.E含量から計算してみると 1 日 15 mgのV.Eを摂取していて, その半量は植物油から摄取 していることになっている。われわれの食用油はおすに ダイズ油であり，米は肧芽を去って精白米としているの でV.Eの供給量は米国人にくらべて少ないと思われる。

われわれが Edwin らの方法で化学的に定量してみる と玄米, 白米各 2 点についてはそれぞれ玄米 $4.3,5.4$ $\mathrm{mg} / 100 \mathrm{~g}$, 白米 $0.5,0.7 \mathrm{mg} / 100 \mathrm{~g}$ であった。このよ5 に精白によってV.Eは著しく減少することを知った。

さて, V.Eのヒトに対する必要性に関しては女性に対 してはまたはっきりした成績が示されていない。しかし 子宝を得られなかった夫婦の男性にV.Eを投与してこれ を治すのに効果を示した例がある。Lindner ${ }^{5)}$ は不妊の 男子55人に $d l \mathrm{~V} . \mathrm{E}$ フセテートを 1 日 $150 \sim 200 \mathrm{mg}$ 与 えた結果18カ月で21人は精子の形態や運動性が改善され
20人は正常になり，17人は子宝を得ることができたと報 告している。

ネズミのばあい.V.Eの欠そで睪丸の萎縮が起きること は知られている。

Braunstein ${ }^{6}$ (は慢性すい臓炎, 輸㫜管閉鎖怙よび肝硬 変の人々を解剖してみると多くのばあい小腸や胃の平滑 筋が褐色に着色していることを認め，この色素は動物の V.E欠乏のばあいに生ずるものと同様であり, 組織の老 化を示するのであることを報告している。このように V.Eの不足はヒトのばあいにも無影響ではないようであ る。

また牛乳中のV.Eは母乳にくらべて少ないため，牛乳 のみを与えた乳児の血液中のV.Eは母乳を飲ませたもの に比べて低く，4〜 5 カ月のときは母乳の $1 / 3$ 程度にな ることが報告されている7゙。このように幼児期にV.Eの 少ないことも乳児に何らかの影響があるであろう。

小柳ら ${ }^{8)}$ はマウスがV.Eに欠乏した状態で好娠すると 胎児に奇形が生ずることを認めている。

なお Weitzel'9) はニワトリやウサギを, 高コレステロ 一ル飼料によって動脈硬化を起こさせるとき，ビタミン A とV.Eとを多量に投与すると動脈硬化か防がれること を報告し，われわれるそれを追試して確かめることがで きた ${ }^{10)}$ 。動脈硬化を防ぐためにリノール酸の摂取が奖め られているが、リノール酸は前述の魚油の脂肪酸と同じ く高度不飽和脂肪酸であるために体内でのV.Eの要求を 高めV.Eの不足を起こしやすいから注意を要する。Horwitt ${ }^{11)}$ はコーン油によって動脈硬化患者にリノール酸を 長期間与えていた結果, 血液中のV.Eが低下することを 認めている。

コーン油にはV.Eは少量含まれているがリノール酸含 量が著しく多いためV.Eは不足になりやすいのである。

\section{要 的}

日本人の主要V.Eの供給源と考えられる食品について ネズミの繁殖を順調に進行させる作用をめやすにして V.Eの効果を判定した。

てんぷら油 2 種のうち一つ, マヨネーズ扰よびキャベ ッはV.Eの効果を認めなかった。しかし，てんぷら油の 他の一種コーンサラダ油はわずかながら効果を示した。 ダイズ扰よび玄米のアルコール抽出物はV.E効果があり 玄米について化学的に定量してみると高濃度にV. Eが含 有されていた。ただ玄米中のV.Eは精白により $1 / 8$ に 著しく減少してしまうことがわかった。

文献

1) King, D. W.: J. Nutr., 83, 123 (1964)

2) Edwin, E. E., Diplock, A. T., Bunyan, J. \& 
Green, J.: Biochem. J., 75, 450 (1960)

3) Harris, P. H., Quaife, M. L. \& Swanson, W. J. : J. Nutr., 40, 367 (1950)

4) Green, J., Marcinkiewicz, S. \& Watt, P. R.: J. Sci. Food Agri., 6, 274 (1955)

5) Lindner, E.: Intern. Z. Vitaminforsch., 29, 33 (1958)

6) Braunstein, H.: Gastroenterology, 40, 224(1960)

7) Canestri, G. \& Piccotti, M. L.: Nutr. Abst. Rev., 31, 1332 (1961)

8）木村䜌一, 安保智子, 小楖達男, 有山恒: ビタ ミン, 34, 8 (1966)
9) Weitzel, G., Schoen, H., Gey, F. \& Buddecke, E.: Z. Physiol. Chem., 304, 247 (1956); 327, 109 (1962)

10）小柳達男, 和田せつ, 室橋正男, 三村二雄: 本誌, 19, 81 (1966)

11) Horwitt, M. K., Harvey, C. C., Century, B. \& Witting, L. A.: Nutr. Abst. Rev., 31, 1332(1961)

(東北大学農学部栄養化学研究室)

* (仙台白百合短 期大学)

\section{貯蔵牛肉中の遊離アミノ酸およひその他の窒素化合物の変化}

牛肉を $4^{\circ}, 9^{\circ}, 15^{\circ} \mathrm{C}$ の三通りの温度で 0〜284 時間 詝藏し, その間の遊離アミノ酸, アンモニア態窒素, 尿 素態窒素, 微生物数の測定をした。詝蔵中にグルタチオ ンとグルタミンは隇少したが，大部分のアミノ酸とくに グルタミン酸とトリプトファンは增加した。グルタミン 酸の増加はバクテリア数と相関があるが, トリプトファ ンの增加は眝蔵時間と温度に直接関係があると考えられ

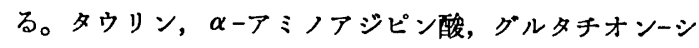
ステインはどの試料中にも認められたが, システイン 酸, シスチン, $\alpha-ア ミ ノ$ 酪酸は新鮮肉には存在せず, 屚敗肉にのみ認められた。尿素熊窒素は詝蔵の初期に增
加するがバクテリアの增殖期に入ると娍少し， $15^{\circ} \mathrm{C}$, 113 時間および $9^{\circ} \mathrm{C} ， 161$ 時閒になると認められなかっ た。アンモニア態窒素は貯藏の初期ではほほ一定でバク テリア增殖期に至り, 增加するが, $4^{\circ} \mathrm{C}$ では增加度はわ ずかであった。（表 4, 図10）

Changes in the Free Amino and Other Nitrogen Compounds in Stored Beef Muscle.

by Gardner, G. A., Stewart, D. J. : J. Sci. Food Agr., 17, 491 496 (1966)

（剣 持） 